\title{
Do Markets and Trade Help or Hurt the Global Food System Adapt to Climate Change?
}

\author{
Food Policy - Viewpoint section \\ Authors: \\ Molly E. Brown, Department of Geographical Sciences, University of Maryland,
} mbrown52@umd.edu

Edward R. Carr, International Development, Community and Environment Department, Clark University, edcarr@clarku.edu

Kathryn L. Grace, Department of Geography, Environment and Society, University of Minnesota Twin Cities, klgrace@umn.edu

Keith Wiebe, International Food Policy Research Institute, k.wiebe@cgiar.org

Christopher C. Funk, Climate Hazards Group, University of California Santa

Barbara,mailto: cfunk@usgs.gov

Witsanu Attavanich, Department of Economics, Kasetsart University, Thailand, witsanu.a@ku.ac.th

Peter Backlund, School of Global Environmental Sustainability, Colorado State University, peter.backlund@colostate.edu

Lawrence Buja, Climate Science and Applications Program, National Center for

Atmospheric Research (NCAR), southern@ucar.edu

\begin{abstract}
Rapidly expanding global trade in the past three decades has lifted millions out of people out of poverty. Trade has also reduced manufacturing wages in high income countries and made entire industries uncompetitive in some communities, giving rise to nationalist politics that seek to stop or reverse further trade expansion in the United States and Europe. Given complex and uncertain political support for trade, how might changes in trade policy affect the global food system's ability to adapt to climate change? Here we argue that we can best understand food security in a changing climate as a double exposure: the exposure of people and processes to both economic and climate-related shocks and stressors. Trade can help us adapt to climate change, or not. If trade restrictions proliferate, double exposure to both a rapidly changing climate and volatile markets will likely jeopardize the food security of millions. A changing climate will present both opportunities and challenges for the global food system, and adapting to its many impacts will affect food availability, food access, food utilization and food security stability for the poorest people across the world. Global trade can continue to play a central role in assuring that global food system adapts to a changing climate. This potential will only be realized, however, if trade is managed in ways that maximize the benefits of broadened access to new markets while minimizing the risks of
\end{abstract}


increased exposure to international competition and market volatility. For regions like Africa, for example, enhanced transportation networks combined with greater national reserves of cash and enhanced social safety nets could reduce the impact of 'double exposure' on food security.

\section{Introduction}

Global trade has grown at twice the rate of the global economy since the 1990s, lifting hundreds of millions of people out of poverty, enhancing competitiveness, expanding economies and improving living standards (WTO, 2016). These benefits have not been felt by everyone. Trade has also reduced manufacturing wages in high income countries and made entire industries uncompetitive in some communities, giving rise to nationalist politics that seek to stop or reverse further trade expansion (Karabarbounis and Neiman, 2014; Timmer et al., 2014).

Increasingly anti-trade rhetoric and protectionist agendas heard in Europe and the United States are emerging as low income countries seek better integration into the global economy (Henson and Loader, 2001; Murina and Nicita, 2015). This demand for participation is particularly acute amongst those countries that suffer a lack of access to sufficient food, since imports can help lower local commodity prices. Over the next decade the food security of hundreds of millions of people will rely heavily on the evolution of global trade.

In the contemporary trade context, a changing climate will present both opportunities and challenges for the global food system. Climate change may affect people and processes in ways that reduce food security by increasing vulnerable people's 'double exposure'. Double exposure results when both economic and climate-related shocks and stressors act together to increase overall vulnerability (O'Brien and Leichenko, 2000). Our perspective is that trade openness can reduce both individual and institutional vulnerabilities by i) enhancing future food security and ii) reducing the cost of response to climate change-induced food availability shocks - if countries have the necessary physical and institutional infrastructure in place (Brown et al., 2015). 


\section{Food Security and Global Food Systems}

Food security is defined as a situation in which "all people at all times have physical, social, and economic access to sufficient, safe, and nutritious food to meet their dietary needs and food preferences for an active and healthy life" (FAO, 2012, 1996). Broadly speaking, food security is comprised of three pillars: food availability, food access, food utilization, as well as the overall stability of each pillar (Pinstrup-Andersen, 2009). Food availability is the existence of food in a particular place at a particular time. Availability addresses the "supply side" of food security, which is determined by food production, transportation, food stocks, storage, and trade (Devereux, 1988).

Once food is present, then the question becomes whether or not a person or group has access to it. Integral to this food security component are issues ranging from the affordability of food to the social roles and responsibilities that govern the allocation of available food within a society (across a range of scales, including intra-nation and intrahousehold) (Higgins et al., 2015; Ploeg et al., 2012). Utilization, or the ability to use and obtain nourishment from food, includes a food's nutritional value and how the body assimilates its nutrients, and touches on climate-sensitive variables such as food safety, sanitation and health (Crimmins et al., 2016).

Finally, the stability of these pillars also shapes food security outcomes. When stable, food availability, access, and utilization do not fluctuate to the point of adversely affecting food security status, either on a seasonal or annual basis or as a result of unpredictable events (FAO, 2012). For example, in 2012, almost the entire United States experienced severe drought, yet food prices exhibited very little fluctuation. Extreme weather, political unrest, or a change in economic circumstances may affect food security by introducing instabilities in one or more components (Sen, 1990).

Access, availability, utilization, and the stability of these three pillars take shape in the context of a global food system (Vermeulen et al., 2012). This system connects producers and consumers through markets that operate at different scales. On one hand, these interconnections can facilitate increased production by providing the income and capital needed to spur new investments in agricultural production or transportation infrastructure that increase the movement of food from producers to consumers. 
These investments can lower the cost of such production and transportation, reducing the price of food and facilitating greater access and choice to most people within this system (WTO, 2015). On the other hand, for some populations there are situations in which the global food system can produce challenges. For example, the increased interconnectedness of food producers and consumers globally can result in the transmission of price shocks produced by distant production crises to people who previously were insulated from such events, such as seen in the food price spikes of 2008 and 2011 (Anderson et al., 2014; Baltzer, 2013).

\section{Climate and the Food System}

Climate change, identified by changes over an extended period in the average and/or variability of properties such as temperature and precipitation, is already affecting major agricultural regions in the world (Walthall et al., 2012). The Intergovernmental Panel on Climate Change (IPCC) finds that human activities have resulted in large changes in Earth's climate over the last few centuries, and much larger changes are projected in the coming decades due to increases in greenhouse gas (GHG) emissions (Crimmins et al., 2016; O’Neill et al., 2014; Rosenzweig et al., 2014; Teixeira et al., 2013; Stocker et al. 2013).

These changes have multiple implications for the global food system. The effect of global climate change on food production (and therefore availability) is well-documented, but is also highly specific to both place and the crop or animal commodity in question (Challinor et al., 2007; Rosenzweig et al., 2014; Sivakumar, 2006; Wang et al., 2009). The effects of changes in climate on crops tend to be gradual until a threshold is reached (IPCC 2013). As the planet warms, more regions may experience temperature-related yield stagnation and even declines, affecting overall food production. Climate change risks can extend beyond agricultural production to other elements of food systems (Vermeulen et al., 2012). Processing, packaging, and storage are very likely to be affected by temperature increases that could increase costs and spoilage. An example is the cooling of fruits and vegetables following harvest to extend shelf life (Kurlansky, 2013), which entails higher energy costs (Moretti et al., 2010).

Packaging and logistics companies in some countries now collaborate with farmers and organizations that seek to reduce food waste to develop packaging that provides ventilation and temperature control (Verghese et al., 2013). Climate change could also make utilization 
more difficult by increasing food safety risks throughout various stages of the food supply chain (Jacxsens et al., 2010; Tirado et al., 2010). For example, increased temperatures are known to cause an increase in diarrheal diseases (which can lead to malnutrition); bacterial foodborne diseases grow and reproduce faster at elevated temperatures (Bandyopadhyay et al., 2012; Tirado et al., 2010).

The impacts of climate change on access are less well understood. Much of the information we have on availability is tied to prices. While the price of food is also an important factor in shaping food access, it is hardly the only factor, and in many cases, may not be the most important factor. Instead, the roles and responsibilities that dictate who has access to food and why can produce food insecurity in places where prices are low, or result in distributions of food that offset the worst food security outcomes in situations where food prices spike (Bellemare, 2015).

Further, even from a market-centric perspective, ports, riverine barge systems, and roads in regions experiencing sea-level rise and changing frequency of climate extremes such as heat waves and drought due to climate change may impede the movement of food from places with surpluses to places with deficits (Attavanich et al., 2013). Such impacts can shape availability and utilization of food in particular places, and also have an impact on access when this infrastructure results in local shortages.

\section{Coupled climate, crop, and economic models}

Framed as a product of double exposure, it is critical to evaluate food security outcomes as the product of linked economic and environmental changes now and into the future if we are to build relevant, productive policies that address future food security (O'Brien and Leichenko, 2000). To this end, coupled climate, crop, and economic models have been used in recent analyses that use scenarios of both high and low GHG emissions to better understand the likely impact of economic and environmental changes on food security (Antle and others, 2015).

Although changes in climate due to anthropogenic factors have been analyzed by models for several decades, when considering food security as the outcome of double exposure, it is not enough to focus only on climatic variables such as rainfall and temperature. Instead, we need scenarios that frame what society (and its attendant economy) may look like by 2050 
or 2100 , for example, and then use these to estimate the probable impacts of the future climate on that future society. Some future societies and economies may be more vulnerable to climate change than others. In the coming decades, some societal changes are likely to be more important for food security outcomes than climate. Factors such as population growth, changes in income, and the affordability of food, will all strongly affect how much food each person can afford to consume.

Technological change in agricultural production and in food processing are particularly difficult to predict and can have a profound effect on food availability and access (Meléndez and Uribe, 2012). Linking models that project agriculturally relevant parameters from climate models to crop models and then to economic models that can project the likely price of food in the future (among other indicators) help us understand the relative importance of these changes to food security in coming decades (Antle and others, 2015; Rosenzweig et al., 2014).

For example, climate models show that over a wide range of scenarios, global temperatures are expected to increase throughout this century. These are likely to be accompanied by longer, more frequent, and more intense temperature extremes and heat waves and increases in regional extreme precipitation events (Stocker et al., 2013). Coupled climate, crop and economic models show that these changes will have consequences for the average and variance of global crop yields, crop production patterns, food prices and effects on food processing, storage, transportation, and retailing (Attavanich and McCarl, 2014; Attavanich et al., 2013; Teixeira et al., 2013; Wiebe et al., 2015). Despite the significant challenges posed by climate change, coupled climate, crop, and economic models show that technological and socioeconomic changes could compensate for changes in climate, resulting in food security outcomes similar to those we experience today (IAC, 2004).

\section{Advantages of Trade for Food Security in a Changing Climate}

Trade is a key way that sufficient calories and nutritious food can be made more available and accessible to those experiencing the greatest climate change impacts. Advances in technology and management practices and the globalization of the food system, including international trade and market connectivity, have enabled widespread diffusion of new technologies and regional agricultural specialization and intensification, resulting in the 
production of sufficient calories for everyone on the planet (Flynn et al., 2009; Garnett et al., 2013; MacDonald et al., 2015). Today, and probably in the foreseeable future, the problem of food security is principally one of distribution of food among nations, regions and households (Figure 1) rather than insufficient overall production.

Moving food to where it is needed involves the means to physically transport foodstuffs, the absence of trade barriers, and the financial wherewithal to purchase adequate nutrition. Trade, as a major driver of economic growth, employment and poverty reduction, often enhances food availability and its stability with differing effects under differing socioeconomic trajectories, such as those described by the shared socioeconomic pathways (SSPs) produced by climate impacts and vulnerability researchers, which describe alternative ways in which global socioeconomic conditions could change over the next century (O'Neill et al., 2014). Under SSP1 and SSP5, world markets would be highly connected and trade would flow easily between countries and regions (Table 1). Under these scenarios, markets are likely to be able to facilitate the movement of food from areas of surplus to areas of deficit. This is likely to reduce food availability challenges created by changes in climate.

Table 1. Shared socioeconomic pathways, trade, market and food security

\begin{tabular}{|c|c|c|c|c|}
\hline $\begin{array}{l}\text { Shared } \\
\text { Socio- } \\
\text { Economic } \\
\text { Pathways }\end{array}$ & Assumptions $^{\mathbf{a}}$ & $\begin{array}{c}\text { Global } \\
\text { Population } \\
\text { by } 2100^{b}\end{array}$ & $\begin{array}{c}\text { Trade and Market } \\
\text { Connectivityc }\end{array}$ & $\begin{array}{l}\text { Food Security } \\
\text { Outcomes }^{\mathrm{d}}\end{array}$ \\
\hline SSP1 & $\begin{array}{l}\text { Low challenges to both } \\
\text { mitigation and adaptation }\end{array}$ & 6.9 billion & $\begin{array}{l}\text { Moderate } \\
\text { international trade } \\
\text { with connected } \\
\text { markets }\end{array}$ & $\begin{array}{l}\text { Relatively food secure, } \\
\text { stresses and shocks in } \\
\text { availability are } \\
\text { compensated with trade }\end{array}$ \\
\hline SSP2 & $\begin{array}{l}\text { Medium challenges to both } \\
\text { mitigation and adaptation }\end{array}$ & 9.0 billion & $\begin{array}{l}\text { Moderate } \\
\text { international trade } \\
\text { with semi-open } \\
\text { globalized economy }\end{array}$ & $\begin{array}{l}\text { Relatively food secure, } \\
\text { stresses and shocks in } \\
\text { availability are anticipated }\end{array}$ \\
\hline SSP3 & $\begin{array}{l}\text { High challenges to both } \\
\text { mitigation and adaptation }\end{array}$ & 12.6 billion & $\begin{array}{l}\text { Strongly constrained } \\
\text { international trade } \\
\text { with de-globalizing, } \\
\text { regional security }\end{array}$ & $\begin{array}{l}\text { Low food security for all, } \\
\text { the poor worse off, better } \\
\text { food security for those } \\
\text { with higher incomes }\end{array}$ \\
\hline SSP4 & $\begin{array}{l}\text { Adaptation challenges dominate } \\
\text { mitigation challenges }\end{array}$ & 9.3 billion & $\begin{array}{l}\text { Moderate } \\
\text { international trade } \\
\text { with globally } \\
\text { connected elites }\end{array}$ & $\begin{array}{l}\text { Low food security, } \\
\text { portions of the population } \\
\text { worse off due to within- } \\
\text { and between-country } \\
\text { inequality }\end{array}$ \\
\hline SSP5 & $\begin{array}{l}\text { Mitigation challenges dominate } \\
\text { adaptation challenges }\end{array}$ & 7.4 billion & $\begin{array}{l}\text { High international } \\
\text { trade and strong }\end{array}$ & $\begin{array}{l}\text { Relatively food secure, } \\
\text { increasing number of }\end{array}$ \\
\hline
\end{tabular}




\begin{tabular}{|c|c|c|c|c|}
\hline & & & $\begin{array}{l}\text { globalization with } \\
\text { connected market }\end{array}$ & $\begin{array}{l}\text { shocks, problems with } \\
\text { availability are } \\
\text { compensated with trade }\end{array}$ \\
\hline
\end{tabular}

Source: a O'Neill et al., (2014), bSamir and Lutz, (2014), ' $\mathrm{O}^{\prime}$ Neill et al., (2015), and dBrown et al. (2015)

On the other hand, SSPs 2, 3, and 4 all present different futures under somewhat constrained market connectivity. Under SSP2, stresses and shocks in availability are anticipated, and the semi-open globalized economy may not be open enough to facilitate the robust trade links needed for markets to effectively respond to these shocks. Under SSPs 3 and 4 this pattern is accentuated. These SSPs present a world where the wealthy enjoy strong trade connections through which they can access goods and resources, but the global poor have few connections to markets and between one another. As a result, markets would be unable to respond fully to shocks and stresses on availability such that food can effectively move into deficit areas to address shortages.

Under SSP3, poor market connectivity also exists among the wealthy of the world, though effects on food availability would almost certainly be less severe than among the poor because greater incomes allow for greater food access. Under SSP4, high within-country inequality could create market-based challenges that diminish food availability for segments of the population within a country. For example, the consumption of meat and other resource-intensive foods under this scenario would divert food away from poorer populations, and low-functioning markets would inhibit trade to areas of deficit created by this pattern of consumption.

Trade also improves household food access by moderating price increases under climate change (Brown and Kshirsagar, 2015; Wiebe et al. 2015; Lybbert and Sumner, 2012). For example, extending earlier AgMIP research with five global economic models to observe the effects of alternative socioeconomic and climate scenarios, Wiebe et al. (2015) found that relative to a world where the climate remains fixed under current conditions, lowemissions/high-international-cooperation scenarios with moderate-to-high levels of global trade exhibit smaller price increases compared with high-emissions/low-internationalcooperation scenarios with restricted levels of global trade . Less trade generally means higher prices, which lead to more food insecure people.

\section{Disadvantages of Trade for Food Security in a Changing Climate}


There are also a number of disadvantages of international trade for poor and remote households that are felt today, and a few which may become more important as the climate continues to change. These include vulnerability to international price shocks that affect local food affordability, and lack of competitiveness in the global marketplace that leads to the inability of local governments to import sufficient food from the international market, and isolation due to poor infrastructure.

Most arguments suggesting that access to international markets has been beneficial to low income countries and agricultural exporters are based on data aggregated at the national or regional level. When we shift analysis to lower levels of spatial scale, we can see that while access to markets provides opportunities, it also introduces new sources of volatility into places that would not otherwise feel the effects of a distant market or climate stress. For example, when global food prices were high in 2008, food costs in Burkina Faso increased sharply, despite above-average domestic agricultural production that year (FAO, 2016). How donors and states address this downside of trade is critical to the long-term viability of the national and global food system.

International trade helps countries attain access to food in an aggregate sense, though it will not by itself increase the within-country availability for isolated people, ensure food access for the poor and socially marginalized, or deal with the health impacts of poor food utilization (Handa and Mlay, 2006). Lack of infrastructure in many food insecure nations in Africa means that there is virtually no formal trade between land-locked countries in northcentral Africa and those in more-developed eastern and southern Africa. High transport costs sustains elevated local producer prices by restricting imports and reducing competition from less expensive alternatives, but this also reduces access to food for the poorest households (Lee et al., 2012).

Increased internal trade within the African continent would promote broader economic and political integration, resulting in lower food costs and higher producer prices through the reduction in necessary transportation and storage costs (Buys et al., 2006). Since many parts of eastern and southern Africa experience inverse relationships to El Niños and La Niñas, increased trade would help mitigate increases in climate variability (Ubilava, 2016). Although poor roads may cause the isolation of rural communities, poor infrastructure may also be due to the lack of goods to trade. Poor institutions and limited endowments of 
productive assets, resulting in little agricultural surplus and few raw materials, result in few transportation links. Built infrastructure has long been recognized as an important element to development and strengthening of local markets to provide affordable food as well as income (Briceño-Garmendia et al., 2004).

International trade helps improve the aggregate welfare of society at the global scale by connecting areas of resource surplus and deficit and lowers demand for land resources on a global level by maximizing production in regions most suited to a crop (Fader et al., 2013). But local and regional markets cannot always ensure food availability within a nation or access to food when incomes are low.

Although there may be enough food for everyone worldwide in an aggregate sense, a particular country may not have sufficient foreign exchange reserves to afford food imports (FAO, 2003). If a region is unable to compete and fails to invest in local infrastructure, a drought or other extreme event that affects local production may result in severe food deficits in a country, as was seen in Zimbabwe in 2008 (Funk and Budde, 2009).

Food affordability depends on the amount of disposable income an individual or family has relative to food prices. For many of the rural poor in developing countries, income depends at least in part on agriculture, which is itself vulnerable to climate variability and change. Low-income households, whose food budgets represent a large portion of their incomes, are more vulnerable to rapid changes in prices than middle- and high-income households because they do not have the economic reserves to increase their food budget (Grosh et al., 2008). Therefore, while smoothing out local production deficits with trade is an important tool to safeguard consumption by the poor, governments and development organizations must also prepare to respond to occasions when markets translate distant shocks into local food insecurity. Increasing local grain reserves might be one way to help insulate national markets.

Care is needed in responding to these concerns, however. During the 2008 food price crisis, export restrictions imposed by major rice-exporting countries were largely responsible for world rice price tripling in four months during a time of record production (Anderson et al., 2014; Bellemare, 2014). Restricting trade (on either imports or exports) may protect the domestic population from the impacts of regional and global economic shocks in the shortterm (Carr, 2011; Do et al., 2013), but over the long term, when trade is restricted, 
producers cannot properly respond with production changes, prices are higher, technology uptake is lower, adaptation is more difficult, and climate effects on food security are worse (Brown et al., 2015).

\section{Conclusions}

In the past few years, fragile food economies in countries that experience El Niño-related droughts face substantial risks (Funk et al., 2016); risks that could be moderated by better functioning markets, international trade, and economic growth that raises incomes in these vulnerable communities (OCHA, 2016). Efforts to evaluate and model these outcomes through the lens of 'double exposure' suggests that trade could play a critical role in ensuring future food security for the widest number of people on the planet.

Trade can benefit agricultural producers and long-term food security in low income countries by supporting producer income through sales of surplus production, and by improving productivity by providing lower-priced or more varied production inputs, such as seed, fertilizer, pesticides, and machinery (Peterman et al., 2014). Low income countries often lack the physical, financial, and government infrastructure necessary for their farmers to compete with other producers around the world who have better infrastructure and superior access to markets (Nkendah, 2010). Fostering efficient and open markets and linking producers to them is important for long-term food security, but also requires effective government policies and support for small producers from actors along the food chain (Reardon et al., 2003).

The rise of anti-establishment, populist parties in the United States, the United Kingdom, and Europe who advocate anti-trade policies that will restrict movement of labor, goods, or services could threaten this progress (Burgoon, 2013). Protectionist policies are attractive in an era of slowing growth since the benefits of trade are diffuse while the costs are concentrated. The impact of protectionist policies on the functioning of the global food system, in the name of national security, political advantage or reducing imperfect competition, should be considered carefully. The burden of information necessary to evaluate the impact of trade interventions increases substantially when considering the added complexity of a changing climate in the agriculture sector (Krugman, 1987). 
As the world seeks to maintain its food system in a changing climate while feeding more people who demand better, more nutritious food, trade policies should be pursued that reduce the impact of double exposure on the global food insecure. The basic arguments supporting trade enhancement and climate mitigation are similar - but sometimes politically difficult - large diffuse benefits are obtained at the expense of concrete concentrated costs. Since the 1950s, continuous market integration and economic growth has helped dramatically increase global wealth and reduce food insecurity. Our analysis of coupled models suggests that deviating from that trajectory will magnify the impact of climate change on food security.

\section{Acknowledgments}

The US Department of Agriculture's Office of the Chief Economist and the CGIAR Research Program on Policies, Institutions, and Markets (PIM) supported this work.

\section{References}

Anderson, K., Ivanic, M., Martin, W.J., 2014. Food Price Spikes, Price Insulation, and Poverty, in: Chavas, J.-P., Hummels, D., Wright, B.D. (Eds.), The Economics of Food Price Volatility. University of Chicago Press, pp. 311-339.

Antle, J.M., others, 2015. Climate change, vulnerability and food insecurity. Choices 30.

Attavanich, W., McCarl, B.A., 2014. How is CO2 affecting yields and technological progress? A statistical analysis. Clim. Change in press.

Attavanich, W., McCarl, B.A., Ahmedov, Z., Fuller, S.W., Vedenov, D. V, 2013. Effects of climate change on US grain transport. Nat. Clim. Chang. 3, 638-643. doi::10.1038/nclimate1892

Baltzer, K., 2013. International to domestic price transmission in fourteen developing countries during the 2007-08 food crisis. United Nations University, Copenhagen.

Bandyopadhyay, S., Kanji, S., Wang, L., 2012. The impact of rainfall and temperature variation on diarrheal prevalence in Sub-Saharan Africa. Appl. Geogr. 33, 63-72.

Bellemare, M.F., 2015. Rising food prices, food price volatility, and social unrest. Am. J. Agric. Econ. 97, 1-21.

Bellemare, M.F., 2014. Comment on "Food Price Spikes, Price Insulation, and Poverty," in: Chavas, J.-P., Hummels, D., Wright, B.D. (Eds.), The Economics of Food Price Volatility. University of Chicago Press, pp. 339 - 344. 
Briceño-Garmendia, C., Estache, A., Shafik, N., 2004. Infrastructure Services In Developing Countries: Access, Quality, Costs and Policy Reform, World Bank Reports WPS 3468. World Bank, Washington DC.

Brown, M.E., Antle, J.M., Backlund, P., Carr, E.R., Easterling, W.E., Walsh, M.K., Ammann, C., Attavanich, W., Barrett, C.B., Bellemare, M.F., Dancheck, V., Funk, C., Grace, K., Ingram, J.S.I., Jiang, H., Maletta, H., Mata, T., Murray, A., Ngugi, M., Ojima, D., O’Neill, B., Tebaldi, C., 2015. Climate Change, Global Food Security, and the U.S. Food System. USDA Technical Document, Washington DC. doi:10.7930/J0862DC7

Brown, M.E., Kshirsagar, V., 2015. Weather and International Price Shocks on Food Prices in the Developing World. Glob. Environ. Chang. 34, 31-40. doi:10.1016/j.gloenvcha.2015.08.003

Burgoon, B., 2013. Inequality and anti-globalization backlash by political parties. Eur. Union Polit. 14, 408-435.

Buys, P., Deichmann, U., Wheeler, D., 2006. Road network upgrading and overland trade expansion in Sub-Saharan Africa. World Bank Publications.

Carr, E.R., 2011. Delivering Development: Globalization's Shoreline and the Road to a Sustainable Future. Palgrave Macmillan.

Challinor, A., Wheeler, T., Garforth, C., Craufurd, P., Kassam, A., 2007. Assessing the vulnerability of food crop systems in Africa to climate change. Clim. Change 83, 381399.

Crimmins, A., Balbus, J., Gamble, J.L., Beard, C.B., Bell, J.E., Dodgen, D., Eisen, R.J., Fann, N., Hawkins, M.D., Herring, S.C., Jantarasami, L., Mills, D.M., Saha, S., Sarofim, M.C., Trtanj, J., Ziska, L., 2016. The Impacts of Climate Change on Human Health in the United States: A Scientific Assessment. , Eds. U.S. Global Change Research Program, Wa, USGCRP. Washington DC. doi:10.7930/J0R49NQX

Devereux, S., 1988. Entitlements, Availability, and Famine. Food Policy 30, 270-282.

Do, Q.-T., Levchenko, A.A., Ravallion, M., 2013. Trade insulation as social protection. The World Bank, Washington DC.

Fader, M., Gerten, D., Krause, M., Lucht, W., Cramer, W., 2013. Spatial decoupling of agricultural production and consumption: quantifying dependences of countries on food imports due to domestic land and water constraints. Environ. Res. Lett. 8, 14046. doi:10.1088/1748-9326/8/1/014046

FAO, 2016. FAO Statistical Database [WWW Document]. 
FAO, 2012. The State of Food Insecurity in the World: Multiple Dimensions of Food Security. United Nations Food and Agriculture Organization, Rome, Italy.

FAO, 2003. Trade Reforms and Food Security: Conceptualizing the Linkages. United Nations Food and Agriculture Organization, Rome, Italy.

FAO, 1996. World Food Summit: Rome Declaration on World Food Security. United Nations Food and Agriculture Organization, Rome, Italy.

Flynn, D.F.B., Gogol-Prokurat, M., Nogeire, T., Molinari, N., Richers, B.T., Lin, B.B., Simpson, N., Mayfield, M.M., DeClerck, F., 2009. Loss of functional diversity under land use intensification across multiple taxa. Ecol. Lett. 12, 22-33.

Funk, C., Harrison, L., Shukla, S., Hoell, A., Korecha, D., Magadzire, T., Husak, G., Galu, G., 2016. Assessing the contributions of local and east Pacific warming to the 2015 droughts in Ethiopia and Southern Africa. Bull. Am. Meteorol. Soc. 97, S75-80. doi:10.1175 /BAMS-D-16-0167.2

Funk, C.C., Budde, M.E., 2009. Phenologically-tuned MODIS NDVI-based production anomaly estimates for Zimbabwe. Remote Sens. Environ. 113, 115-125.

Garnett, T., Appleby, M.C., Balmford, A., Bateman, I.J., Benton, T.G., Bloomer, P., Burlingame, B., Dawkins, M., Dolan, L., Fraser, D., Herrero, M., Hoffmann, I., Smith, P., Thornton, P.K., Toulmin, C., Vermeulen, S.J., Godfray, H.C.J., 2013. Sustainable Intensification in Agriculture: Premises and Policies. Science (80-. ). 341, 33-34.

Grosh, M., Ninno, C. del, Tesliuc, E., Ouerghi, A., 2008. For Protection and Promotion: The Design and Implementation of Effective Safety Nets. The World Bank, Washington DC.

Handa, S., Mlay, G., 2006. Food consumption patterns, seasonality and market access in Mozambique. Dev. South. Afr. 23, 541-560.

Henson, S., Loader, R., 2001. Barriers to agricultural exports from developing countries: the role of sanitary and phytosanitary requirements. World Dev. 29, 85-102.

Higgins, N., Hintermann, B., Brown, M.E., 2015. A model of West African millet prices in rural markets. Food Policy 52. doi:10.1016/j.foodpol.2014.09.011

IAC, 2004. Realizing the promise and potential of African agriculture - Science and technology strategies for improving agricultural productivity and food security in Africa. IAC Secretariat The Netherlands, Amsterdam, the Netherlands.

Jacxsens, L., Luning, P.A., der Vorst, J., Devlieghere, F., Leemans, R., Uyttendaele, M., 2010. Simulation modelling and risk assessment as tools to identify the impact of climate change on microbiological food safety--The case study of fresh produce supply chain. 
Food Res. Int. 43, 1925-1935.

Karabarbounis, L., Neiman, B., 2014. The global decline of the labor share. Q. J. Econ. 129, 61-103.

Krugman, P.R., 1987. Is free trade pass\{é\}? J. Econ. Perspect. 1, 131-144.

Kurlansky, M., 2013. Birdseye: The Adventures of a Curious Man. Anchor.

Lee, J., Gereffi, G., Beauvais, J., 2012. Global value chains and agrifood standards: Challenges and possibilities for smallholders in developing countries. Proc. Natl. Acad. Sci. 109, 12326-12331.

Lybbert, T.J., Sumner, D.A., 2012. Agricultural technologies for climate change in developing countries: Policy options for innovation and technology diffusion. Food Policy 37, 114123. doi:10.1016/j.foodpol.2011.11.001

MacDonald, G.K., Brauman, K.A., Sun, S., Carlson, K.M., Cassidy, E.S., Gerber, J.S., West, P.C., 2015. Rethinking Agricultural Trade Relationships in an Era of Globalization.

Bioscience 65, 275-289. doi:10.1093/biosci/biu225

Meléndez, M., Uribe, M.J., 2012. International Product Fragmentation and the Insertion of Latin America and the Caribbean in Global Production Networks: Colombian Case Studies . Inter-American Development Bank. doi:http://publications.iadb.org/bitstream/handle/11319/4264/International\%20pr oduct\%20.pdf?sequence $=1$

Moretti, C.L., Mattos, L.M., Calbo, A.G., Sargent, S.A., 2010. Climate changes and potential impacts on postharvest quality of fruit and vegetable crops: a review. Food Res. Int. 43, 1824-1832.

Murina, M., Nicita, A., 2015. Trading with Conditions: The Effect of Sanitary and Phytosanitary Measures on the Agricultural Exports from Low-income Countries. World Econ.

Nkendah, R., 2010. The Informal Cross-Border Trade of agricultural commodities between Cameroon and its CEMAC's Neighbours, in: Paper for the NSF/AERC/IGC Conference.

O’Brien, K.L., Leichenko, R.M., 2000. Double exposure: assessing the impacts of climate change within the context of economic globalization. Glob. Environ. Chang. 10, 221232.

O’Neill, B.C., Kriegler, E., Ebi, K.L., Kemp-Benedict, E., Riahi, K., Rothman, D.S., van Ruijven, B.J., van Vuuren, D.P., Birkmann, J., Kok, K., others, 2015. The roads ahead: narratives for shared socioeconomic pathways describing world futures in the 21st century. Glob. 
Environ. Chang.

O’Neill, B.C., Kriegler, E., Riahi, K., Ebi, K.L., Hallegatte, S., Carter, T.R., Mathur, R., van Vuuren, D.P., 2014. A new scenario framework for climate change research: the concept of shared socioeconomic pathways. Clim. Change 122, 387-400.

OCHA, 2016. El Nino: overview of impact, projected humanitarian needs and response. New York, NY.

Peterman, A., Behrman, J.A., Quisumbing, A.R., 2014. A Review of Empirical Evidence on Gender Differences in Nonland Agricultural Inputs, Technology, and Services in Developing Countries, in: Quisumbing, R.A., Meinzen-Dick, R., Raney, L.T., Croppenstedt, A., Behrman, A.J., Peterman, A. (Eds.), Gender in Agriculture: Closing the Knowledge Gap. Springer Netherlands, Dordrecht, pp. 145-186. doi:10.1007/978-94017-8616-4_7

Pinstrup-Andersen, P., 2009. Food security: definition and measurement. Food Secur. J. 1, 57.

Ploeg, M. Ver, Breneman, V., Farrigan, T., Hamrick, K., Hopkins, D., Kaufman, P., Lin, B.-H., Nord, M., Smith, T.A., Williams, R., Kinnison, K., Olander, C., Singh, A., Tuckermanty, E., 2012. Access to Affordable and Nutritious Food: Measuring and Understanding Food Deserts and Their Consequences . Economic Research Service, US Department of Agriculture, Washington DC.

Reardon, T., Timmer, C.P., Barrett, C.B., Berdegué, J., 2003. The rise of supermarkets in Africa, Asia, and Latin America. Am. J. Agric. Econ. 85, 1140-1146.

Rosenzweig, C., Elliott, J., Deryng, D., Ruane, A.C., Müller, C., Arneth, A., Boote, K.J., Folberth, C., Glotter, M., Khabarov, N., others, 2014. Assessing agricultural risks of climate change in the 21st century in a global gridded crop model intercomparison. Proc. Natl. Acad. Sci. 111, 3268-3273.

Samir, K.C., Lutz, W., 2014. The human core of the shared socioeconomic pathways: Population scenarios by age, sex and level of education for all countries to 2100. Glob. Environ. Chang.

Sen, A., 1990. Food, Economics and Entitlements, in: Dreze, J., Sen, A. (Eds.), The Political Economy of Hunger. Clarendon Press, New York, pp. 10-45.

Sivakumar, M.V.K., 2006. Climate prediction and agriculture: current status and future challenges. Clim. Res. 33, 3-17.

Stocker D. Qin, G.-K. Plattner, M. Tignor, S.K. Allen, J. Boschung, A. Nauels, Y. Xia, V. Bex and 
P.M. Midgley, T.F., 2013. Climate Change 2013: The Physical Science Basis.

Contribution of Working Group I to the Fifth Assessment Report of the Intergovernmental Panel Climate Change. Cambridge University Press, Cambridge, United Kingdom and New York, NY, USA. doi:10.1017/CB09781107415324.

Teixeira, E.I., Fischer, G., Velthuizen, H. van, Walter, C., Ewert, F., 2013. Global hot-spots of heat stress on agricultural crops due to climate change. Agric. For. Meteorol. 170, 206215. doi:10.1016/j.agrformet.2011.09.002

Timmer, M.P., Erumban, A.A., Los, B., Stehrer, R., de Vries, G.J., 2014. Slicing up global value chains. J. Econ. Perspect. 28, 99-118.

Tirado, M.C., Clarke, R., Jaykus, L.A., McQuatters-Gollop, A., Frank, J.M., 2010. Climate change and food safety: A review. Food Res. Int. 43, 1745-1765.

Ubilava, D., 2016. The Role of El Niño Southern Oscillation in Commodity Price Movement and Predictability. Sydney, NSW Australia.

Verghese, K., Lewis, H., Lockrey, S., Williams, H., 2013. The role of packaging in minimising food waste in the supply chain of the future: Prepared for: CHEP Australia.

Vermeulen, S.J., Campbell, B.M., Ingram, J.S.I., 2012. Climate Change and Food Systems. Annu. Rev. Environ. Resour. 37, 195-222. doi:10.1146/annurev-environ-020411130608

Walthall, C.L., Hatfield, J., Backlund, P., Lengnick, L., Marshall, E., Walsh, M., Adkins, S., Aillery, M., Ainsworth, E.A., Ammann, C., Anderson, C.J., Bartomeus, I., Baumgard, L.H., Booker, F., Bradley, B., Blumenthal, D.M., Bunce, J., Burkey, K., Dabney, S.M., Delgado, J.A., Dukes, J., Funk, A., Garrett, K., Glenn, M., Grantz, D.A., Goodrich, D., Hu, S., Izaurralde, R.C., Jones, R.A.C., Kim, S.-H., Leaky, A.D.B., Lewers, K., Mader, T.L., McClung, A., Morgan, J., Muth, D.J., Nearing, M., Oosterhuis, D.M., Ort, D., Parmesan, C., Pettigrew, W.T., Polley, W., Rader, R., Rice, C., Rivington, M., Rosskopf, E., Salas, W.A., Sollenberger, L.E., Srygley, R., Stöckle, C., Takle, E.S., Timlin, D., White, J.W., Winfree, R., WrightMorton, L., Ziska, L.H., 2012. Climate change and agriculture in the United States: Effects and adaptation, USDA Technical Bulletin 1935. U.S. Department of Agriculture., Washington DC.

Wang, J., Mendelsohn, R., Dinar, A., Huang, J., Rozelle, S., Zhang, L., 2009. The impact of climate change on China's agriculture. Agric. Econ. 40, 323-337.

Wiebe, K., Lotze-Campen, H., Sands, R., Tabeau, A., van der Mensbrugghe, D., Biewald, A., Bodirsky, B., Islam, S., Kavallari, A., Mason-D’Croz, D., others, 2015. Climate change 
impacts on agriculture in 2050 under a range of plausible socioeconomic and emissions scenarios. Environ. Res. Lett. 10, 85010.

WTO, 2016. The Global Enabling Trade Report 2016. New York City, New York.

WTO, 2015. Falling import demand, lower commodity prices push down trade growth prospects. Geneva, Switzerland. 
Figure 1. Global, country and household climate impacts

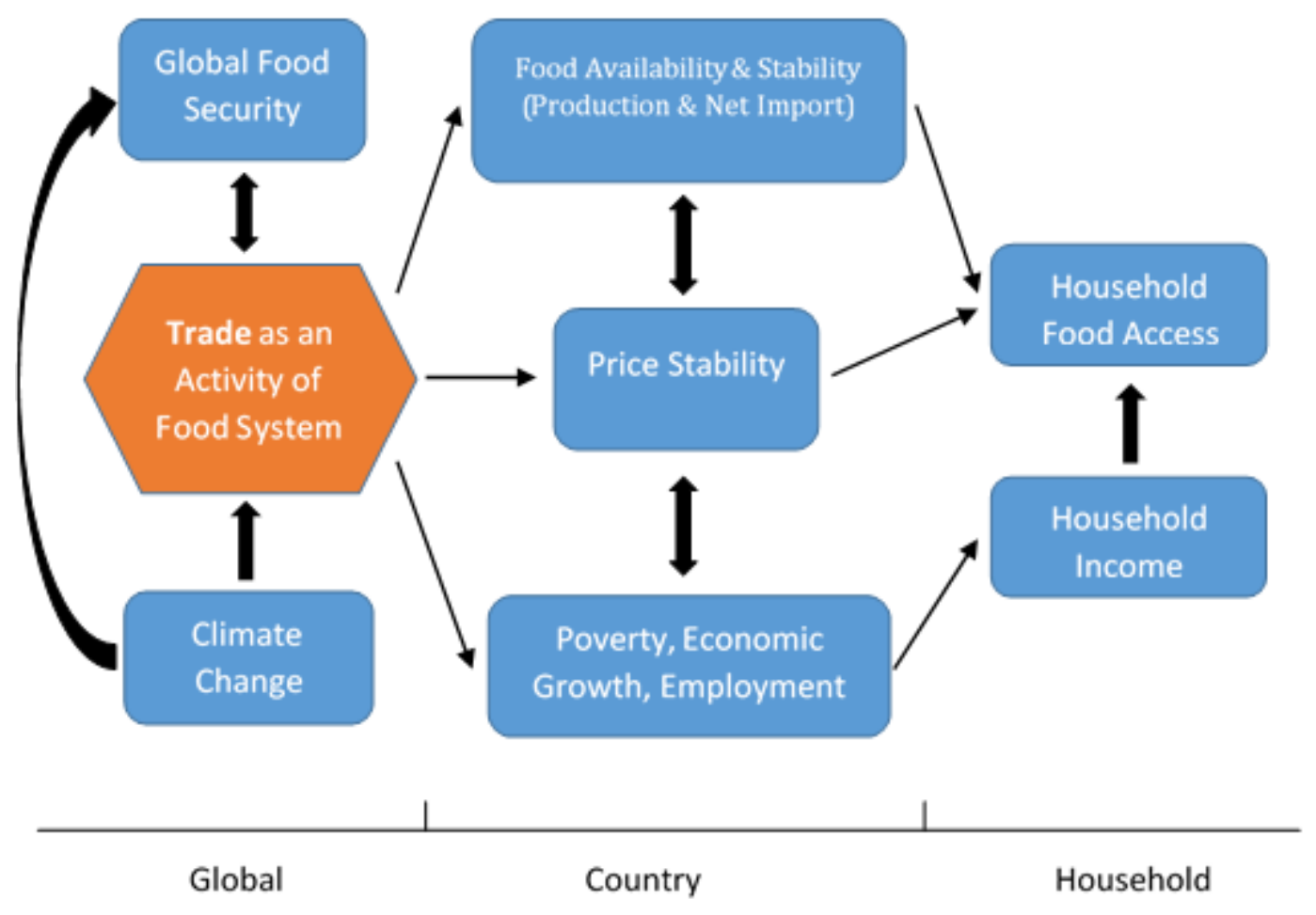

